\section{Preservation of Dental Sockets Filled with Composite Bovine Bone. A Single-Blind Randomized Clinical Trial}

\author{
Vail Natale Júnior ${ }^{1}$, Francisley Ávila Souza ${ }^{2}$, Eduardo Vedovatto ${ }^{1}$, Renato \\ Sussumu Nishioka ${ }^{3}$, Pier Paolo Poli ${ }^{4}$, Paulo Sérgio Perri de Carvalho ${ }^{1,2}$
}

'Implant Dentistry Post-Graduation

Program, School of Dentistry and Research Center SLMANDIC

- Faculdade de Medicina e

Odontologia e Centro de Pesquisas

Odontológicas São Leopoldo

Mandic, Campinas, SP, Brazil

${ }^{2}$ Department of Surgery and Integrated Clinic, Araçatuba Dental

School, UNESP - Universidade

Estadual Paulista, Araçatuba, SP, Brazil

${ }^{3}$ Department of Dental Materials and

Prosthodontics, Institute of Science and Technology - ICT, UNESP -

Universidade Estadual Paulista,

São José dos Campos, SP, Brazil ${ }^{4}$ Implant Center for Edentulism and

Jawbone Atrophies, Maxillofacial Surgery and Odontostomatology Unit, Fondazione IRCCS Cà Granda Maggiore Policlinico Hospital,

University of Milan, Milan, Italy.

Correspondence: Prof. Francisley Ávila Souza, Rua José Bonifácio, 1193, 16015-050 Araçatuba, SP, Brasil. Tel: +55-18-3636 2898.

e-mail: francisley.avila@unesp.br

Key Words: biocompatible materials; bone remodeling; bone substitutes; tooth socket; wound healing.

\section{Introduction}

The increase in human life expectation demands that medical sciences adopt an attitude focused on prevention and health promotion, to provide better quality of life. However, a large number of people continue to need restorative and rehabilitative treatments. This is no different in oral health. Brazilian public health data reported that around $70 \%$ of the Brazilian population of approximately 40 years of age present with the loss of one or more teeth (1). These rates rise as the age range evaluated increases.

Thus, osseointegration becomes the first choice for rehabilitating these patients, because it is a safe and predictable technique both for rehabilitating single and multiple tooth losses. The end purpose is to re-establish function and esthetics. However, as a result of the etiology of tooth loss and time elapsed after extraction, accentuated alveolar bone resorption may occur (2). These cases may require additional procedures for reconstructing the alveolar bone, for later insertion of osseointegrated implants in a more favorable prosthetic position $(3,4)$.

Alveolar bone resorption after tooth loss is a continuous and irreversible process. The mean rate of alveolar bone resorption in the anterior maxillary region during the first year after tooth loss is around 25\% of total bone volume; the reduction in alveolar bone thickness may reach up to $40-60 \%$ by the 3 rd year after tooth loss (5). For the posterior region of the maxilla, alveolar bone loss may reach up to $50 \%$ of total volume during the course of 3 years $(6,7)$. However, studies have pointed out that the initial volume of the posterior maxilla is twice as large as the anterior maxilla (8).

Therefore, the dimensional changes of the dental alveolus after tooth loss are a factor causing great concern in oral rehabilitation with the use of osseointegrated implants. In this sense, great importance is attached to the development of techniques that make it possible to maintain the alveolar bone volume after the extraction procedure. Guided bone regeneration (GBR) techniques are the most used type for alveolar bone maintenance, by using the biologic property of osteopromotion (9). The biologic concepts of osteopromotion seeks to maintain a biologic space by means of barriers and membranes, so that cells that have a faster metabolism than cells of osteoblastic origin do not differentiate first, forming fibrous tissue, and impeding differentiation into bone tissue (10). The final purpose will be to promote osseous proliferation. The technique may be associated with the use of biomaterials that serve as a structure to keep the membrane in position, allowing a more effective result (11). Among the biomaterials, heterologous bone of bovine 
origin provided good results (12).

Bone substitutes of heterogeneous origin have been cited in the literature as an option for guided bone regeneration, because they present predictable results (13). They have the advantages of: lower morbidity; absence or reduction of alveolar bone loss; a single surgical procedure, without requiring a second surgical site to obtain bone, among others (14). Heterogeneous composite bone of bovine origin has both inorganic content, represented by hydroxyapatite, and organic content, represented by freeze-dried remnant proteins, mainly collagen type I. The composite bone substitute used in this study has in its constitution 33,33\% organic portion, 33,33\% natural collagen, and 33,33\% inorganic portion represented by heterogeneous hydroxyapatite. Such biomaterial showed a good biologic response; good levels of bone biocompatibility, allowing bone growth by apposition; that is, this material has the biologic property of osteoconduction (15).

A previous experimental study (16) evaluated bone healing of surgically created critical size defects treated with same composite bovine bone (Gen-Mix, Baumer SA, Mogi Mirim, SP, Brazil) in ovarectomized rats, and $\vec{s}$ the authors suggested that the composite bovine bone placed in the critical defects was biocompatible and osteocondutive in all the experimental groups. On the other hand, a randomized clinical trial study (17) using the composite bone graft evaluated the hard and soft tissue modifications in fresh socket with and without soft tissue primary closure in a split-mouth design. In conclusion, ridge bone preservation was performed in both groups. In view of the foregoing, the aim of this study was to clinically evaluate the preservation of the alveolar dimensions in human extraction sockets filled with heterologous composite bone of bovine origin.

\section{Material and Methods}

This study was approved by the Research Ethics Committee of the Dentistry Research Center (CPO) of São Leopoldo Mandic Research Center, under Protocol Number 2010/0195. It was designed in concordance with the CONSORT guidelines (www.consort-statement.org) and ethical principles for medical research involving human subjects from the Declaration of Helsinki. This clinical trial has been registered with the Brazilian registry of clinical trials (URL: http://www.ensaiosclinicos.gov.br/rg/ edit/5519/)

Fifty-eight record charts were selected from the database of patients enrolled to dental treatment at the São Leopoldo Mandic School of Dentistry and Research Center, Campinas, Brazil. All of these patients required extraction of a single tooth for subsequent implant-supported rehabilitation. The inclusion criteria were as follows:

a) Patients who needed extraction of a single tooth for subsequent implant placement;

b) Patients ranging from 18 to 45 years of age; not reporting systemic diseases, with a good general health status compatible with surgical risk ASA I;

c) Patients with good oral health status free of periodontal diseases;

d) Patients with teeth/and or roots not presenting periapical lesions;

e) After the extraction procedure, the socket had to present intact bone walls, without perceptible fractures of the bone plates;

f) Patients who accepted the conditions of this study, after reading and signing the term of free informed consent.

The exclusion criteria were established in compliance with the following parameters: pregnant women and smokers.

After application of the inclusion criteria (Fig. 1), the study was conducted with 40 patients. Seventeen patients were excluded because not meeting inclusion criteria: nine patients presented bone fracture of the alveolar socket walls after the extraction, three patients presented periapical lesion diagnosed in pre-operative radiographic examination, two patients presented active periodontal disease, three patients were not ASA I surgical risk and one patient refused to participate in this study. The sample number was determined by calculated of power test through website http://www.lee.dante.br/pesquisa/ amostragem/amostra.html. Level of significance of 5\% and power test of 95\% were adopted, and it was suggested twenty patients per group. Enrolled patients underwent tooth extraction between August 2011 and January 2015.

\section{Patients and Groups}

Forty mono-radicular teeth were extracted in 40 patients (one tooth per patient). All surgical procedures were performed by a single operator with experience in the surgical field following the CONSORT flow diagram (Fig. 1). This study followed a randomized, single-blind, controlled design. Sealed envelopes containing the name of each patient were numbered from 1 to 40 . The number sequence was lottery to the website www.randomization. com. Simple randomization of the patients (1:1 allocation ratio) to the control $(n=20)$ and biomaterial $(n=20)$ groups was performed through a computer-generated random number table by a blinded researcher uninvolved with operative procedures or patient care, who kept a list of codes and informed the surgeon. The patients were blinded with respect to the grafting material used to fill the alveolar socket, composite bovine bone or blood clot.

The procedures performed in the groups are described 
bellow:

Biomaterial Group: after tooth extraction, the alveolar socket was filled with heterologous composite bovine bone graft (Gen-Mix).

Control Group: after tooth extraction, the alveolar socket was filled with blood clot.

\section{Surgical Procedure}

All the patients in this study underwent preventive antibiotic therapy with $2 \mathrm{~g}$ of Amoxicillin $1 \mathrm{~h}$ before the surgical procedure. Anesthesia was induced by infiltrative terminal technique in the area corresponding to the tooth to be extracted, using an anesthetic solution of lidocaine hydrochloride 2\% with epinephrine (Alphacaine 1:100.000, DFL, São Paulo, SP, Brazil). The extraction procedures were carefully performed with minimally invasive techniques, in order to maintain the integrity of the alveolar bone plates. Syndesmotomy was performed with a \#15 scalpel blade (Feather, Feather Safety, Japan). After syndesmotomy the extraction was performed with forceps (Quinelato, São Carlos, SP, Brazil) when the cervical portion of the tooth was intact, or by Seldin type extractors (Quinelato) when the tooth could not be extracted by means of forceps. After extraction, the walls of the alveolus were explored with a Lucas curette (Quinelato) to ensure their integrity. The fresh socket was then irrigated with saline, followed by a

\section{CONSORT \\ TRANSPARENT REPORTING Of TRIALS}

CONSORT 2010 Flow Diagram

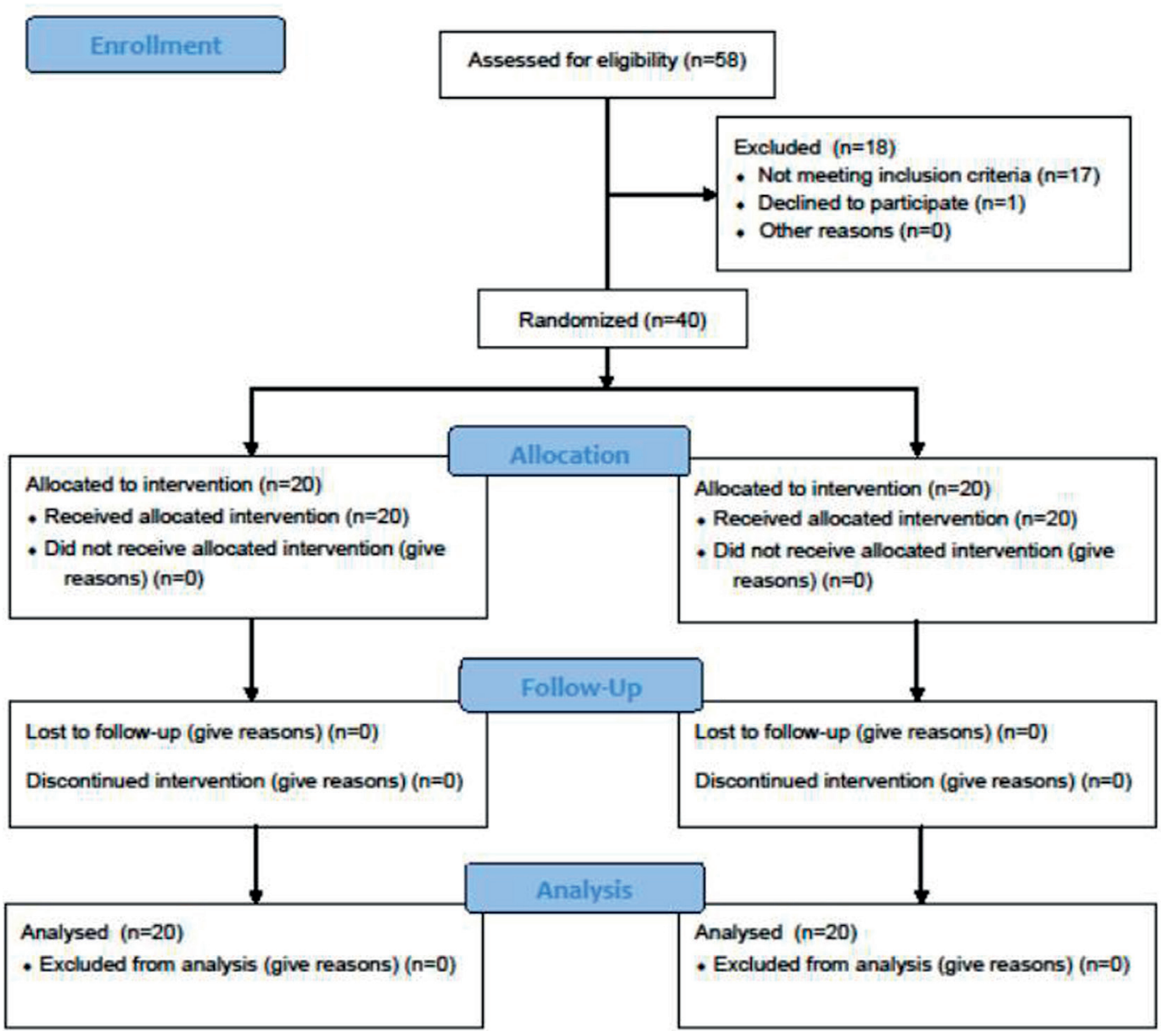

Figure 1. CONSORT flow diagram inherent to the present clinical trial. 
gentle compression of the alveolar walls with a sterile gauze.

\section{Obtaining the Clinical Measurements of the Dental Alveolus}

The fresh sockets were measured at their greatest buccal-palatine/lingual - BP/L (Fig. 2A) and mesiodistal MD (Fig. 2B) distances by means of a dry point compass (ICE, São Paulo, SP, Brazil) according to a previous study (14). The distances were immediately checked with a digital caliper (Zaas, Precision, São Paulo, SP, Brazil), noted and tabulated. All clinical procedures and measurements were performed by a single operator, using magnifying glass (Protécni, Araraquara, SP, Brazil) to enhance viewing.

After obtaining the alveolar measurements of the fresh socket the patients were randomly divided into 2 groups: the Biomaterial Group and the Control Group. In the Biomaterial Group, post-extraction sockets were filled with composite bovine bone, previously dampened and agglutinated with physiological solution. In the Control Group, alveolar sockets were left to heal spontaneously with blood clot. Finally, in both groups a fibro-mucosal plug was removed from the maxillary retromolar region, with the use of a circular $5.0 \mathrm{~mm}$ diameter scalpel (Dentoflex, São Paulo, SP, Brazil) (Fig. 3A). The gingival plug was used as a natural biologic barrier, and was sutured with polyglactin 910 thread (Vicryl, Johnson \&Johnson, São Paulo, SP, Brazil) on the cervical portion of the alveolus (Fig. 3B).

In the post-operative period the patients were followed up with monthly recalls to clinically evaluate the alveolar repair process. After 120 days, the patients underwent the second surgical procedure for implant insertion. An incision was made in the alveolar crest, as recommended, to raise
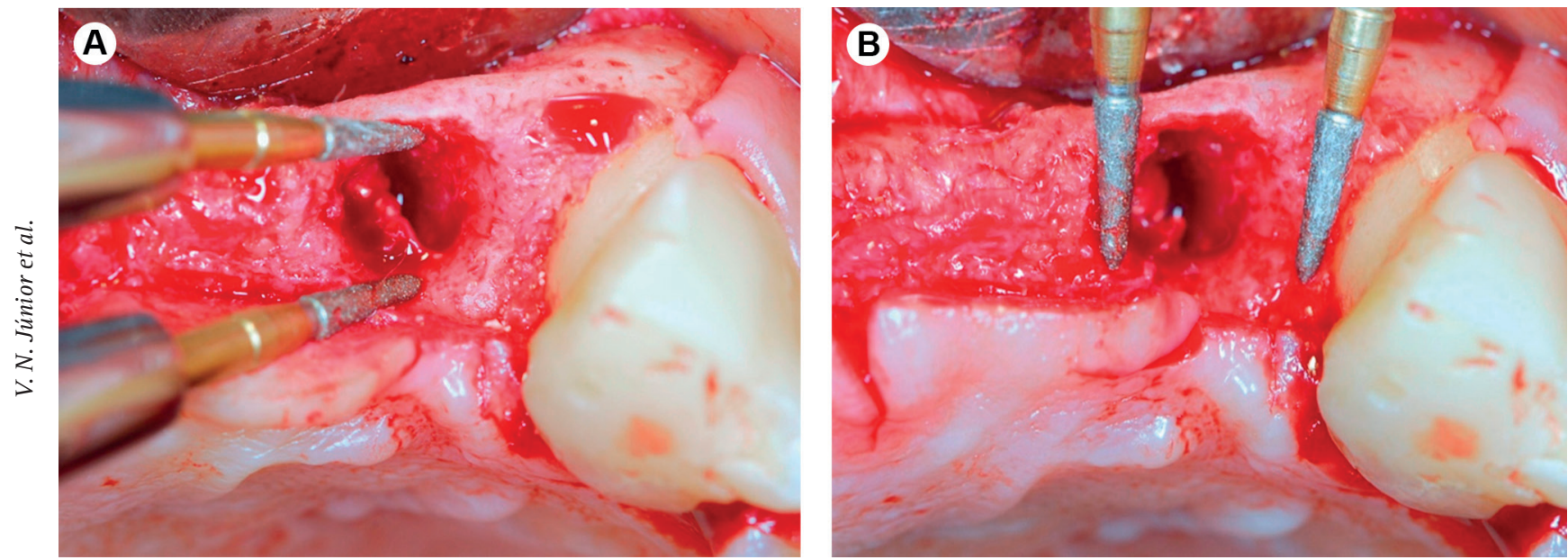

Figure 2. A: The fresh socket measured at the greatest buccal-palatine/lingual distance. B: The fresh socket measured at the greatest mesiodistal distance.
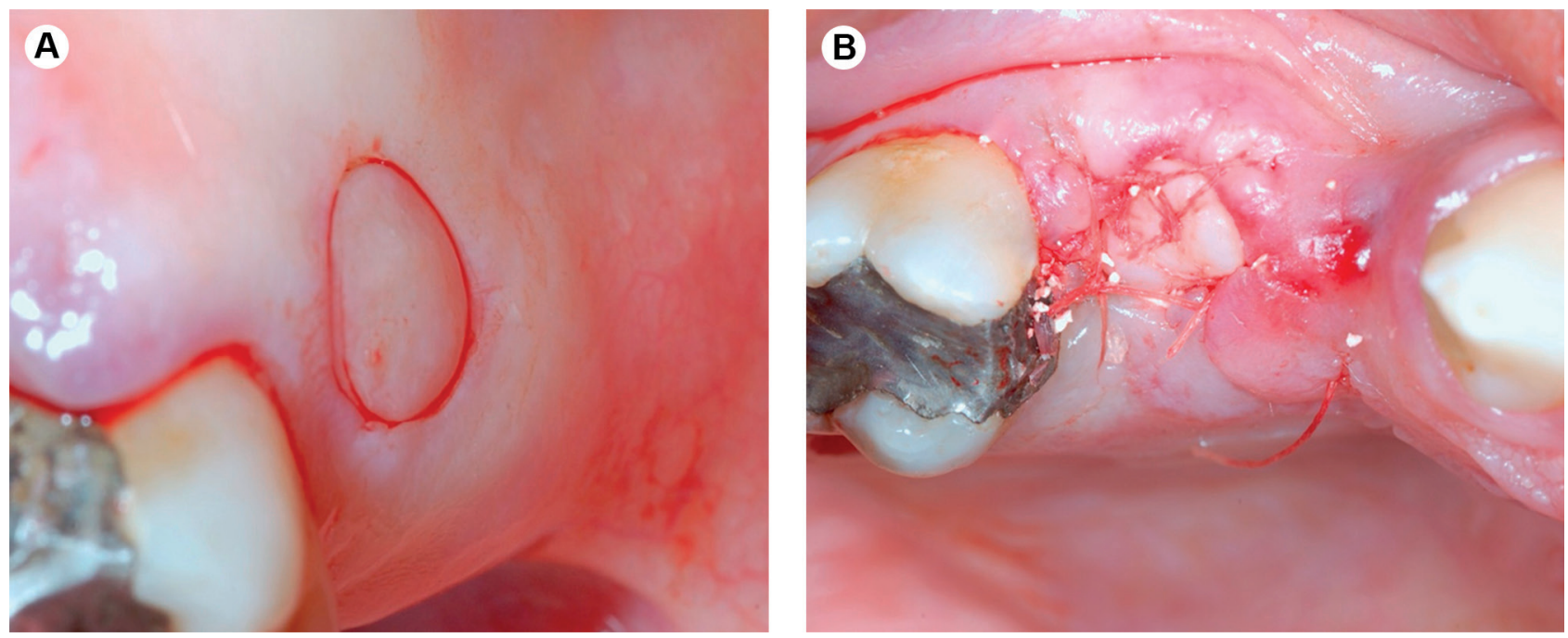

Figure 3. A: Fibro-mucosal plug delimited on the maxillary retromolar region. B: Fibro-mucosal plug sutured on the cervical portion of the alveolus. 
a mucoperiosteal flap in order to expose the recipient bed. Before implant placement, the same protocol was used to measure the greatest mesiodistal and buccallingual/palatine distances that had been established and standardized in the first measurement. The data were noted and tabulated.

Statistical Analysis

The numerical data obtained were processed with twoway ANOVA and Fisher's exact test $(\alpha=0.05)$.

\section{Results}

Of the 40 patients submitted to the extraction procedure, 24 were women and 16 men, with an age-range between 18 and 45 years (mean age: 33.2 years). Overall, 20 patients were enrolled in the biomaterial group, and 20 in the control group. In the biomaterial group, 12 extractions were performed in the maxilla, and 8 in the mandible, whereas in the control group, 10 extractions were performed in the maxilla, and 10 in the mandible. No adverse effect was observed after treatment for the 40 participants.

\section{Clinical Measures of the Dental Alveolus}

When analyzing the 40 extractions performed in the maxilla and mandible, in the biomaterial group the mean values obtained for the mesiodistal (MD) and buccallingual/palatine (BL/P) dimensions were $4.95 \mathrm{~mm}$ and 6.08 $\mathrm{mm}$ respectively, in the period immediately after extraction; and $4.87 \mathrm{~mm}$ and $5.88 \mathrm{~mm}$ at the second stage surgery, 120 days post-operatively. In the control group, the mean values obtained for the MD and BL/P dimensions were $5.23 \mathrm{~mm}$ and $6.13 \mathrm{~mm}$ respectively in the period immediately after extraction; and $4.97 \mathrm{~mm}$ and $5.69 \mathrm{~mm}$ at the second stage surgery. A reduction in percentage of $1.62 \%$ and $3.29 \%$ in the $\mathrm{MD}$ and $\mathrm{BL} / \mathrm{P}$ dimensions was observed 120 days after the extraction in the biomaterial group; whereas a reduction of $4.97 \%$ and $7.18 \%$ in the $\mathrm{MD}$ and $\mathrm{BL} / \mathrm{P}$ dimensions was found in the control group.

Table 1 . Statistical analysis between the biomaterial and control groups

\begin{tabular}{|c|c|c|c|c|c|}
\hline & Distance & Difference (\%) & $\begin{array}{l}\text { Standardized } \\
\text { difference (\%) }\end{array}$ & p value* & Significant \\
\hline $\begin{array}{l}\text { Maxillae biomaterial vs } \\
\text { Maxillae control }\end{array}$ & BP & 5.885 & 4.197 & $0.001^{*}$ & Yes \\
\hline $\begin{array}{l}\text { Maxillae biomaterial vs } \\
\text { Maxillae control }\end{array}$ & MD & 5.525 & 3.466 & $0.007^{*}$ & Yes \\
\hline $\begin{array}{l}\text { Mandible biomaterial vs } \\
\text { Mandible control }\end{array}$ & BL & 0.997 & 0.669 & 0.908 & No \\
\hline $\begin{array}{l}\text { Mandible biomaterial vs } \\
\text { Mandible control }\end{array}$ & MD & 1.292 & 2.273 & 0.122 & No \\
\hline
\end{tabular}

* Indicates statistically significant difference.
When analyzing the maxilla separately, in the biomaterial group the mean values were $5.31 \mathrm{~mm}$ (MD) and $6.66 \mathrm{~mm}$ (buccal-palatine (BP)) immediately after the extraction; and $5.24 \mathrm{~mm}$ and $6.46 \mathrm{~mm}$ at 120 days. In the control group, the mean values were $5.74 \mathrm{~mm}$ (MD) and $6.41 \mathrm{~mm}$ (BP) immediately after extraction; and 5.37 $\mathrm{mm}$ and $5.81 \mathrm{~mm}$ at 120 days. In the biomaterial group, a reduction in percentage of $1.32 \%$ and $3.00 \%$ in the MD and BP dimensions of the alveolar socket was found 120 days after the extraction; in the control group, a reduction of 6.45\% and 9.36\% in the MD and BP dimensions was observed 120 days after the extraction.

When analyzing the extractions performed in the mandible, in the biomaterial group the mean values obtained for the measurements MD and buccal-lingual (BL) were $4.59 \mathrm{~mm}$ and $5.51 \mathrm{~mm}$ in the period immediately after extraction; and $4.50 \mathrm{~mm}$ and $5.30 \mathrm{~mm}$ at 120 days. In the control group, the mean values obtained for the measurements $\mathrm{MD}$ and $\mathrm{BL}$ were $4.73 \mathrm{~mm}$ and $5.85 \mathrm{~mm}$ in the period immediately after extraction; and $4.58 \mathrm{~mm}$ and $5.58 \mathrm{~mm}$ at 120 days. A reduction in percentage of 1.96\% and $3.81 \%$ in the MD and BL measurements of the alveoli was found 120 days after extraction for the biomaterial group; and a reduction of $3.17 \%$ and $4.61 \%$ in the MD and BL measurements of the alveoli was observed at 120 days for the control group.

\section{Statistical Analysis}

There was a statistically significant difference between the biomaterial and the control group for the measurements and reduction (in percentage) of the alveolar socket in the bucco-palatal $(p=0.001)$ and mesiodistal $(p=0.007)$ dimension for the maxilla (Table 1). Therefore, the reduction in percentage of the alveolus in the buccal-palatine direction in the biomaterial groups was statistically lower when compared to the reduction in percentage of the alveolus in the buccal-palatine dimension in the control group only for the maxilla (Fig. 4). As well, the reduction in percentage of the alveolus in the mesiodistal direction in the biomaterial group was statistically lower when compared to the reduction in percentage of the alveolus in the mesiodistal direction in the control group only for the maxilla (Fig. 5). In the measurements and reduction in percentage of the alveolus in the mesiodistal and buccallingual direction for the mandible there were no 
statistically significant difference between the two groups.

\section{Discussion}

Considering that the basic prerequisite for osseointegrated implant placement in a favorable prosthetically guided position is the quantity of bone, maintenance of alveolar volume after tooth extraction becomes an essential step. One of the procedures most frequently used with this purpose is GBR. The GBR technique is based on the biologic property of osteopromotion in which a membrane acts as a physical barrier when it is placed over a bone defect, preventing differentiation and penetration of cells with a faster metabolism than that of bone tissue, such as the fibroblasts present in fibrous connective tissue (18). Among other applications, this technique is indicated for the alveolus after tooth extraction, with the purpose of maintaining the thickness and height of alveolar bone tissue, with or without inserting biomaterials. Therefore, with the aim of minimizing dimensional changes in the alveolus after the bone repair process, GBR with or without the use of biomaterials has been used (19-25).

In the present study, no alveolar covering was performed by means of traditional membranes, such as the absorbable collagen membranes (26) or polylactic glycolic acid (27) membranes. In this study, we used a fibro-mucosal plug obtained from the maxillary retromolar region, sutured on the edges of the alveolar mucosa. This technique was similar to that used in a published previous study (14). Although the fibro-mucosal plug has the disadvantage of requiring a donor site that increases the surgical morbidity, it has the advantage of being a biologic barrier that directs epithelialization of the entry to the alveolus, in addition to protecting and maintaining the implanted bone substance within the alveolus.

The dimensional changes in the alveolus after tooth extraction have been extensively discussed in the scientific literature $(14,20,22,26,28-30)$. Published previous studies $(22,28)$ have used experimental models with a long period of observation of the dimensional changes during the alveolar repair process. However, in this study, we sought to simulate the procedures routinely performed in daily clinical practice: when it is impossible to insert implants immediately after extraction, a short period is waited for alveolar repair to occur, and then place the implants afterwards. This short period of alveolar repair is due to the knowledge of the dimensional changes in the alveolus after tooth extraction, in which there is a loss of alveolar volume to a thickness of up to $50 \%$ of the original bone width after 12 months (14), that may reach up to $60 \%$ of the total volume after 3 years (5).

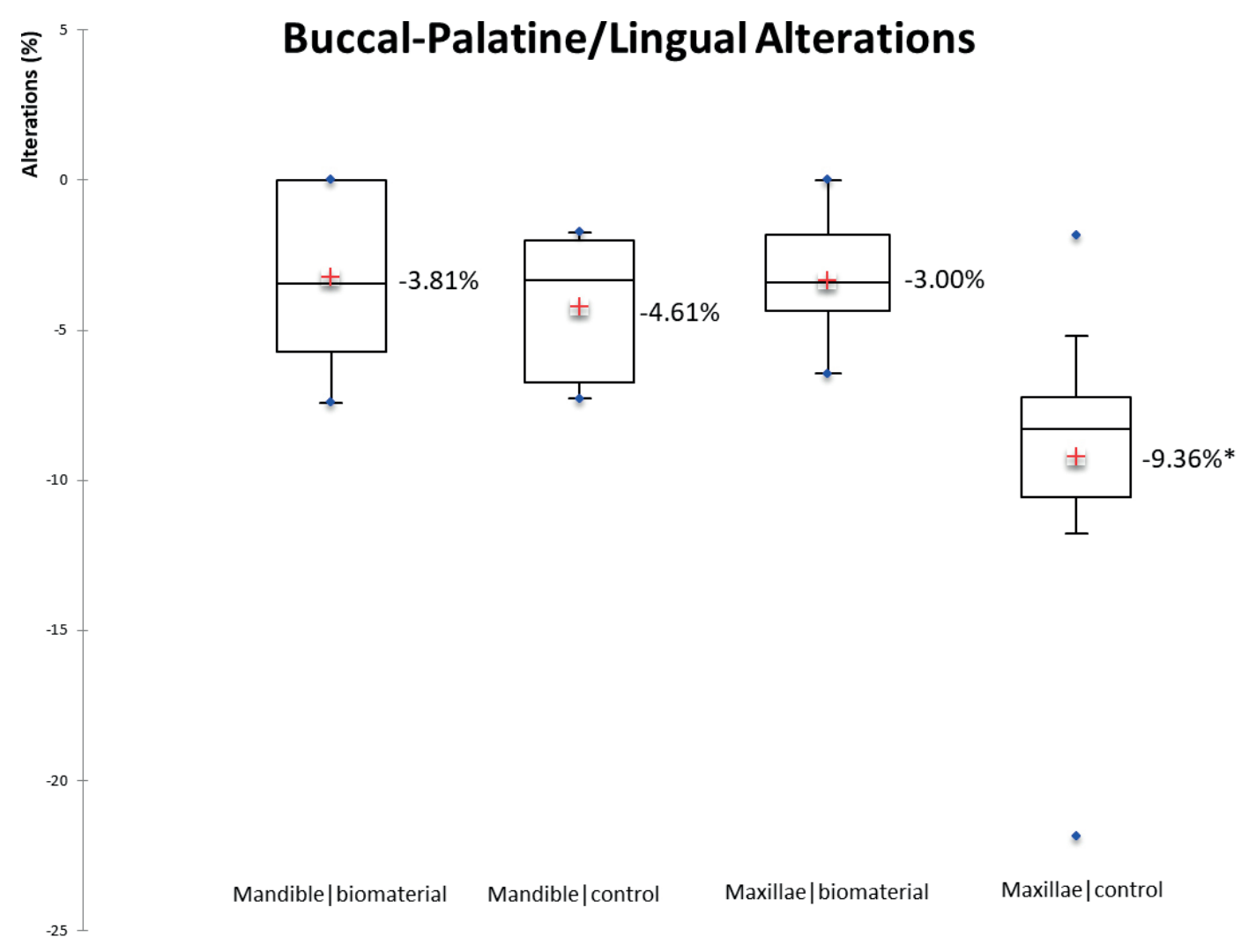

Figure 4. Reduction in percentage of the alveolus in the buccal-palatine/lingual region in the maxilla and mandible for the biomaterial and control groups. *Statistically significant difference $(\mathrm{p}<0.001)$. Two-way ANOVA, Fischer's exact test. 
In this study we observed the dimensional changes in the alveolus 4 months after the tooth extractions, in bone defects classified as those of 5 walls (31). In these defects of 5 walls, complete restoration of the morphology and volume of the residual alveolar ridge occurred after bone repair (8). This fact may be observed in our study when we analyzed the dimensional changes in the alveolus in the control group, in which there was a loss of $9.36 \%$ in the buccal-palatine direction, and $6.45 \%$ in the mesiodistal direction in the maxilla; and $4.61 \%$ and $3.17 \%$ respectively in the mandible. Although this loss in bone dimensions occurred after 4 months, in general it did not represent a significant loss that could prevent the placement of implants due to alveolar deficiency. Whereas, in the biomaterial group, in which the alveolus was filled with substitute bone composite, it was possible to observe a bone loss of $3.81 \%$ in the buccal-palatine direction and 1.96\% in the mesiodistal direction in the maxilla; and 3.00\% and $1.32 \%$, respectively, in the mandible. These data obtained in our study were similar to those found in previous studies $(14,23)$, in which the authors showed that the use of bone substitutes in post-extraction alveoli had the potential of limiting alveolar bone loss, and not of avoiding it.

The methodology used in this study presented the difficultly of establishing the limits of the repaired alveoli, particularly in the mesiodistal direction. However, the changes in the alveolus in the mesiodistal direction normally have no great clinical repercussion, and the difficulty found was similar in the biomaterial and control groups, both in the maxilla and mandible. Perhaps this fact explains the results found in this study in which there were no statistically significant differences between the control and biomaterial groups when we analyzed the dimensional reduction of the alveolus in the mesiodistal direction only for the mandible. However the authors highlight that the results obtained in this study for the measurements and loss of alveolar dimensions in the mesiodistal direction showed that there was statistically significant difference between the control and biomaterial groups only for the maxillae.

Whereas, the difficulty of establishing the limits of the repaired alveoli in the buccal-lingual/palatine direction were far smaller. The results obtained in this study for the measurements and loss of alveolar volume in the buccalpalatine direction showed that there was statistically significant difference between the control and biomaterial groups only for the maxillae. This result may be explained, because bone remodeling is more significant in the maxillae due to the fact that the bone thickness of the maxillary buccal plate is smaller than that of the mandibular buccal bone plate (22).

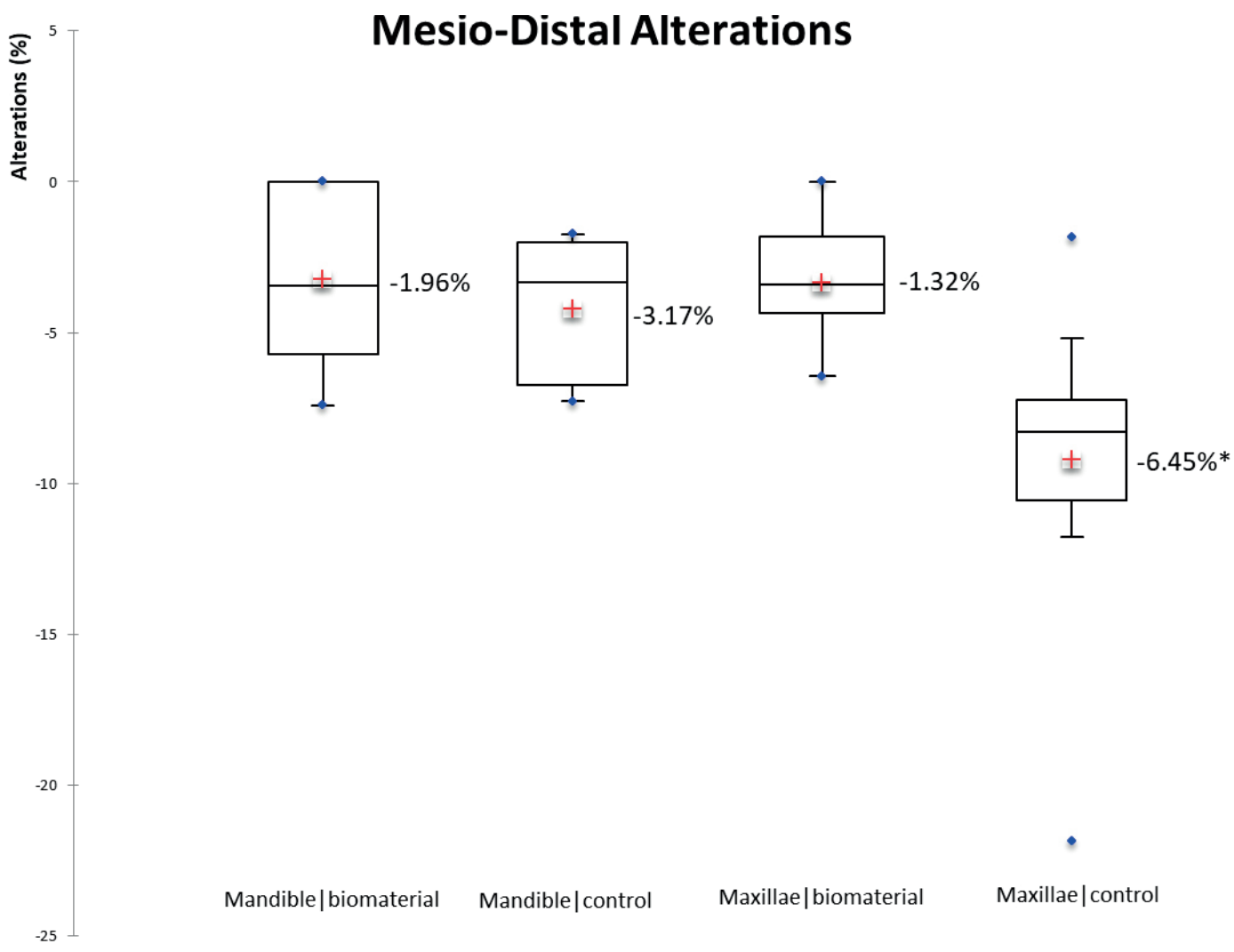

Figure 5. Reduction in percentage of the alveolus in the mesiodistal region in the maxilla and mandible for the biomaterial and control groups. *Statistically significant difference ( $\mathrm{p}<0.007)$. Two-way ANOVA, Fischer's exact test. 
Previous studies in animals (32) and humans (33) have demonstrated that the immediate placement of implants in fresh alveoli was unable to avoid dimensional changes in the alveolus after tooth extraction. The key factor for remodeling of alveoli appears to be the thickness of the buccal bone plate $(22)$. Previous studies $(34,35)$ have suggested that a minimum buccal bone plate thickness of $1-2 \mathrm{~mm}$ is necessary to maintain a stable vertical dimension of the alveolar crest.

Huynh-Ba et al. (35) measured the buccal and palatine walls in 93 fresh socket in the maxilla. The authors found a mean thickness of $0.8 \mathrm{~mm}$ in the vestibular bone plate for the anterior region of the maxilla (canine to canine) and $1.1 \mathrm{~mm}$ thickness for the posterior region of the maxilla (Premolar). In this same study, the authors reported that $87 \%$ of the buccal bone walls had widths smaller than or equal to $1 \mathrm{~mm}$, and only $3 \%$ of the walls were $2 \mathrm{~mm}$ thick. In the premolar region, the corresponding values were $59 \%$ and $9 \%$, respectively. These data suggest that in the majority of extractions performed in the anterior region of the maxilla, the residual buccal alveolar bone plate will be thin $(\leq 1 \mathrm{~mm})$, that would interfere negatively in the dimensional change of the alveolus after the bone repair

-palatine and mesiodistal direction, with statistically significant difference $(p<0.05)$ when compared with the biomaterial group.

The authors of this work believe that the thickness of the buccal and palatine walls must be analyzed with greater attention in any situation when the aim is to maintain the alveolar volume. In addition it is necessary to fill any gap there may be between the implant and alveolar walls greater than $1 \mathrm{~mm}$. Also point out that in this study no material was obtained for histopathological exam, for ethical reasons, and the biomechanical test of insertion torque of implants was not included after the alveolar repair, because the focus of our evaluation was the alveolar volume.

Therefore, this article contributed to the study of preserving alveolar volume after extraction, and its clinical relevance allows the authors declare that the use of biomaterials, specifically composite bone bovine in fresh socket modulates the level of alveolar remodeling, providing a greater amount of bone tissue after alveolar repair. This fact provides more predictable results in prosthetic rehabilitation with the use of osseointegrated implants. However, the authors highlight that this study evaluated only the dimensional alterations of the alveolus by means of clinical measures without the biological evaluation of the newly formed bone tissue by means of histological and histometric analyzes, among others, and by this fact further researches should be conducted to evaluate with biomechanical, and if possible, biological values, as well as the advantage of using different intra-alveolar bone substitutes before implant placement. In view of the results obtained, it's concluded that the composite bovine bone graft limited, but did not impede alveolar bone remodeling even in short periods as 120 days after the dental extraction.

\section{Resumo}

0 objetivo deste estudo foi avaliar em humanos a manutenção do volume em alvéolos frescos preenchidos por osso integral de origem bovina por meio de um estudo clínico randomizado com monocegamento. Quarenta dentes uni radiculares foram extraídos em 40 pacientes (um dente em cada participante), e apos estes pacientes foram divididos aleatoriamente em 2 grupos: indivíduos que tiveram o alvéolo fresco preenchido por osso integral de origem bovina (Grupo Biomaterial) ou por coagulo sanguineo (Grupo Controle). Apos a exodontia os alvéolos foram medidos em suas maiores distancias mesio-distal (MD) e vestíbulo lingual/palatina (VL/P) por meio de compasso de ponta seca. 0 fechamento primário dos alvéolos foi realizado com um tampão fibromucoso. Apos 120 dias pós-operatórios durante o procedimento de reabertura foram obtidas novamente as maiores medidas MD e VL/P para calcular em porcentagem o nivel de remodelação do osso alveolar. No grupo biomaterial observou-se uma redução em porcentagem de 1,62\% e 3,29\% nas medidas MD e VL/P 120 dias apos as extrações, enquanto no grupo controle houve uma redução de $4,97 \%$ e $7,18 \%$ nas medidas MD e VL/P no mesmo período. Houve diferença estatisticamente significante $(p<0,05)$ entre os dois grupos para as medidas vestíbulo/palatina e mesiodistal na maxila. Diante dos resultados obtidos conclui-se que o osso integral de origem bovina limitou, mas não impediu a remodelação óssea alveolar.

\section{Acknowledgements}

This trial was conducted with institutional funds from Araçatuba Dental School, São Paulo State University "Júlio de Mesquita Filho", Araçatuba, SP, Brazil and São Leopoldo Mandic School of Dentistry and Research Center, Campinas, Brazil.

\section{References}

1. Brazil SB. 2010: National Research on Oral Health: Main results / Ministério da Saúde. Secretaria de Atenção à Saúde. Secretaria de Vigilância em Saúde. - Brasília: Ministério da Saúde, 2012.

2. Araujo MG, Silva CO, Misawa M, Sukekava F. Alveolar socket healing: what can we learn? Periodontol 2000 2015;68:122-134.

3. Klokkevold PR, Han TJ, Camargo PM. Aesthetic management of extractions for implant site development: delayed versus staged implant placement. Pract Periodontics Aesthet Dent 1999;11:603-610; quiz 12.

4. Benic $\mathrm{Gl}$, Hammerle $\mathrm{CH}$. Horizontal bone augmentation by means of guided bone regeneration. Periodontol 2000 2014;66:13-40.

5. Carlsson GE, Bergman B, Hedegard B. Changes in contour of the maxillary alveolar process under immediate dentures. A longitudinal clinical and x-ray cephalometric study covering 5 years. Acta Odontol Scand 1967;25:45-75.

6. Atwood DA. Reduction of residual ridges: a major oral disease entity. J Prosthet Dent 1971;26:266-279.

7. Tallgren A. The continuing reduction of the residual alveolar ridges in complete denture wearers: a mixed-longitudinal study covering 25 years. J Prosthet Dent 1972;27:120-132.

8. Misch CE. Contemporary Implant Dentistry. 3rd ed. St Louis: Mosby Elsevier; 2009. 
9. de Santana RB, de Mattos CM, Francischone CE, Van Dyke T. Superficial topography and porosity of an absorbable barrier membrane impacts soft tissue response in guided bone regeneration. J Periodontol 2010;81:926-933.

10. von Arx T, Buser D. Horizontal ridge augmentation using autogenous block grafts and the guided bone regeneration technique with collagen membranes: a clinical study with 42 patients. Clin Oral Implants Res 2006;17:359-366.

11. Retzepi M, Donos N. Guided Bone Regeneration: biological principle and therapeutic applications. Clin Oral Implants Res 2010;21:567-576.

12. Zitzmann NU, Scharer $P$, Marinello $C P$, Schupbach $P$, Berglundh T. Alveolar ridge augmentation with Bio-Oss: a histologic study in humans. Int J Periodontics Restorative Dent 2001;21:288-295.

13. Jung $\mathrm{RE}$, Fenner $\mathrm{N}$, Hammerle $\mathrm{CH}$, Zitzmann NU. Long-term outcome of implants placed with guided bone regeneration (GBR) using resorbable and non-resorbable membranes after 12-14 years. Clin Oral Implants Res 2013;24:1065-1073.

14. Fickl S, Zuhr O, Wachtel H, Stappert CF, Stein JM, Hurzeler MB. Dimensional changes of the alveolar ridge contour after different socket preservation techniques. J Clin Periodontol 2008;35:906-913.

15. Stein RS, Silva JB, Silva VD. Comparative study of bone neoformation using autologous grafting and three replacements: bone defects in rats. Rev Bras Ortop 2009:44:330-335.

16. de Almeida JM, Bosco AF, Faleiros PL, Pazmiño VF, Murakawa AC, Bonfante $S$, et al. Effects of oestrogen deficiency and $17 \beta$-estradiol therapy on bone healing in calvarial critical size defects treated with bovine bone graft. Arch Oral Biol 2015;60:631-641.

17. Engler-Hamm D, Cheung WS, Yen A, Stark PC, Griffin T. Ridge preservation using a composite bone graft and a bioabsorbable membrane with and without primary wound closure: a comparative clinical trial. J Periodontol 2011;82:377-387.

18. Sculean A, Nikolidakis D, Schwarz F. Regeneration of periodontal tissues: combinations of barrier membranes and grafting materials biological foundation and preclinical evidence: a systematic review. J Clin Periodontol 2008;35:106-116.

19. De Coster P, Browaeys H, De Bruyn H. Healing of extraction sockets filled with BoneCeramic ${ }^{\oplus}$ prior to implant placement: preliminary histological findings. Clin Implant Dent Relat Res 2011;13:34-45.

20. Smukler $H$, Landi $L$, Setayesh R. Histomorphometric evaluation of extraction sockets and deficient alveolar ridges treated with allograft and barrier membrane: a pilot study. Int J Oral Maxillofac Implants 1999;14:407-416.

21. Polimeni G, Koo KT, Qahash M, Xiropaidis AV, Albandar JM, Wikesjo UM. Prognostic factors for alveolar regeneration: effect of a spaceproviding biomaterial on guided tissue regeneration. J Clin Periodontol 2004;31:725-729.

22. Araujo $M G$, Lindhe J. Dimensional ridge alterations following tooth extraction. An experimental study in the dog. J Clin Periodontol
2005:32:212-218.

23. Checchi V, Savarino L, Montevecchi M, Felice P, Checchi L. Clinicalradiographic and histological evaluation of two hydroxyapatites in human extraction sockets: a pilot study. Int J Oral Maxillofac Surg 2011;40:526-532.

24. Crespi R, Cappare P, Gherlone E. Comparison of magnesium-enriched hydroxyapatite and porcine bone in human extraction socket healing: a histologic and histomorphometric evaluation. Int J Oral Maxillofac Implants 2011;26:1057-1062.

25. Beretta M, Cicciu M, Poli PP, Rancitelli D, Bassi G, Grossi GB, et al. A Retrospective Evaluation of 192 Implants Placed in Augmented Bone: Long-Term Follow-Up Study. J Oral Implantol 2015;41:669-674.

26. Serino $G$, Biancu $S$, lezzi $G$, Piattelli A. Ridge preservation following tooth extraction using a polylactide and polyglycolide sponge as space filler: a clinical and histological study in humans. Clin Oral Implants Res 2003;14:651-658.

27. Wang HL, Tsao YP. Mineralized bone allograft-plug socket augmentation: rationale and technique. Implant Dent 2007;16:33-41.

28. Cardaropoli G, Araujo M, Lindhe J. Dynamics of bone tissue formation in tooth extraction sites. An experimental study in dogs. J Clin Periodontol 2003;30:809-818.

29. Cardaropoli G, Araujo M, Hayacibara R, Sukekava F, Lindhe J. Healing of extraction sockets and surgically produced - augmented and nonaugmented - defects in the alveolar ridge. An experimental study in the dog. J Clin Periodontol 2005;32:435-440.

30. Maiorana C, Poli PP, Deflorian M, Testori T, Mandelli F, Nagursky H, et al. Alveolar socket preservation with demineralised bovine bone mineral and a collagen matrix. J Periodontal Implant Sci 2017;47:194-210.

31. Misch CE, Dietsh F. Bone-grafting materials in implant dentistry. Implant Dent 1993;2:158-167.

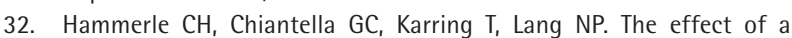
deproteinized bovine bone mineral on bone regeneration around titanium dental implants. Clin Oral Implants Res 1998;9:151-162.

33. Paolantonio M, Dolci M, Scarano A, d'Archivio D, di Placido G, Tumini V, et al. Immediate implantation in fresh extraction sockets. A controlled clinical and histological study in man. J Periodontol 2001;72:15601571.

34. Grunder U, Gracis S, Capelli M. Influence of the 3-D bone-toimplant relationship on esthetics. Int J Periodontics Restorative Dent2005;25:113-119.

35. Huynh-Ba G, Pjetursson BE, Sanz M, Cecchinato D, Ferrus J, Lindhe J, et al. Analysis of the socket bone wall dimensions in the upper maxilla in relation to immediate implant placement. Clin Oral Implants Res 2010;21:37-42. 